\title{
Young People, Risk Taking and Risk Making: Some Thoughts for Social Work ${ }^{1}$
}

\section{Elaine Sharland}

Key words: young people, risk, habitus, theory, constructivism, social work

\begin{abstract}
Policy makers, professionals and the public have become increasingly concerned with identifying and managing young people who are not only troubled or at risk, but troubling or risky. Social work, however, has been relatively silent on the subject. In social work practice, young people have become largely "someone else's problem"; in the academy, relatively little critical attention has been given to their risk taking, or to the way we "make" or construct it. This paper takes an exploratory rather than systematically comprehensive journey, across a range of discursive terrains, to open up the debate. Examining current concerns with youth and risk, it explores some of the social and psychological theory bases whereby youth is constructed as a risky business. Drawing on empirical research from several disciplines, it examines patterns and dynamics of young people's risk taking, and explores concepts of risk culture and cultural learning, identity capital and BOURDIEU's notion of "habitus", to frame these. The discussion high-lights the need for critically reflective social work to understand the complex interplay of identity and agency, structure, culture and context that underpins young people's risk taking. It encourages us to scrutinise our judgements of what is acceptable or unacceptable riskiness, what within and what beyond the pale.
\end{abstract}

\section{Table of Contents}

1. Young People and Risk—Locating the Problem

2. Young People Behaving Badly? Public Perceptions, Policy Responses

3. Constructing Youth as a Risky Business

4. Research and Theoretical Insights

5. Conclusion-Implications for Social Work

References

Author

Citation

\section{Young People and Risk—Locating the Problem}

The idea of youth at risk has become central to a range of discourses, academic and professional. In the regional and global contexts of significant social, economic and technical change, narratives of risk and uncertainty are widespread (BECK et al. 1994; BECK 1999; GIDDENS 1999). Young people, meanwhile, are seen both as a treasured resource and as endangered and dangerous-at risk. from others, to themselves, and to the fabric of communities (KELLY 2000a, $2000 \mathrm{~b}, 2003)$. The category of "youth at risk", and the imperatives to protect, monitor, contain and sustain young people in the transition to responsible adulthood, have come to the fore on multiple intellectual and professional agendas. [1]

1 This article was first published in the British Journal of Social Work: Advance Access, 17 October 2005: doi:10.1093/bjsw/bch254. 
Politicians and policy makers are increasingly exercised by how to prevent young people from taking or being exposed to risk, from becoming socially excluded, deviant, unhealthy or unproductive (SOCIAL EXCLUSION UNIT 1999, 2000a, 2000b; HOME OFFICE 2003; OFFICE OF NATIONAL STATISTICS 2004). However, in social policy and social work, there are some noteworthy ambivalences and gaps in the way that young people and risk are currently framed. Meanwhile, academic social work discourse is surprisingly quiet on the topic. A brief tour of national and international social work journals reveals that there is a dearth of work dedicated specifically to young people as a category, let alone to youth and risk. Where such work appears, it does so only with reference to discrete subgroups, presenting distinct problems, for targeted concern. On the "welfare" side of the care/control divide, we see care leavers, teenage parents, young homeless, addicts or those with mental health problems, considered as discrete populations of youth at risk (BUNTING \& MCAULEY 2004a, 2004b; DAVIS et al. 2002; STEAD et al. 2004; STEVENS 2004). Slightly more prominent, perhaps, have been those on the "control" side of the divide-young people increasingly highlighted in policy as troublesome rather than troubled, at risk of offending or simply being offensive (GOLDSON 2000, 2002; D. SMITH 2003; R. SMITH 2003; WHYTE 2004). [2]

Striking, however, in its absence from academic social work is a wider discourse on the status of risk in young people's lives, our understanding and response to it -this in a context where popular, professional and policy wisdoms denote adolescence and youth as a period of "storm and stress", when individuals are more than ever likely to become risky to themselves and others. [3]

From this discursive absence stem two further observations. First, what is difficult to discern from the literature are the understandings that currently guide social work practice with young people and risk. Perhaps it is simply naive to search for these now? The most cursory conversation with practitioners about social work with young people in the UK context raises eyebrows either in puzzlement or resignation. In climates of resource restriction and narrowing of the social work role within the wider preventive agenda, mainstream social work practice with young people is a luxury rarely afforded (DEPARTMENT OF HEALTH 1996). More and more, responsibility for young people "belongs" to other agencies, public, voluntary, independent or community sector-a shift no doubt accentuated by the growing separation of children's from adult services, with young people falling (in)conveniently between. On top comes the implicit sliding scale of professional blame culture, with culpability for child protection failures judged even more heinous for younger children than older; thus the former, of necessity, is prioritised. That it may be naive to search now for the research and theory bases of social work with young people may be true. But this is no argument for ignoring the case for social work with young people at risk, nor indeed for ignoring research and theoretical insights to inform it. [4]

A second observation is that there is a wealth of research and theoretical discussion about young people and risk, taking place within a range of disciplines under the broad, if multi-coloured, umbrella of youth studies. Despite their 
heterogeneity, most commentators share a vision of young people as a risky population, either by definition or by virtue of the contemporary world they live in. Academic social work debate has taken little of this on board. This paper aims to make a start. [5]

In doing so, several challenges are faced. The first is simply defining the terms of youth and risk for consideration. Clearly, it makes sense to distinguish in the detail between thirteen and twenty-year-olds. To open the broader debate, however, it is helpful to consider research and theory that concerns all those from early teens to twenty. As for risk, the focus here will be on risk taking as opposed to risk exposure, acknowledging that that the two are in multiple ways connected. Here too it is important to distinguish in the detail between, for example, practising unsafe sex, school exclusion, alcohol abuse or criminality. To begin the debate, however, young people and risk taking merit consideration in the round. [6]

More challenging is the task of making connections between the very different empirical and theoretical discursive strands within youth and risk studies, all too often either tangled or passing each other by (COHEN \& AINLEY 2000; FRANCE 2000; KELLY 2000b). Psychology, social theory, sociology, medicinal science, criminology, educational and cultural studies have brought to the field different objects and processes of enquiry, different knowledges, different truths. This paper marks a beginning not an end to teasing from this web some coherent and constructive threads for social work to follow. [7]

The discussion looks first at current concerns with, and responses to, young people and risk, focusing on the British context. Turning then to the wider national and international literature, it explores some of the theoretical bases on which youth is constructed as a risky business, examining, as the title of the paper suggests, both risk taking and risk making. The former focuses on questions of agency, structure and identity. The latter reflects critically on the ways in which young people, and youth itself, have become constituted as risky. Finally, the discussion turns to specific research and theoretical developments that might inform social work understanding and practice. [8]

\section{Young People Behaving Badly? Public Perceptions, Policy Responses}

Historically, public discourses have used young people as a barometer of social ills, with whatever threats they appear to pose taken as indicators of society's moral decline (BRANNEN et al. 1994). Currently, this seems more than ever so, with mounting evidence marshalled, feeding public anxiety and neo-liberal policy reaction (CÔTÉ 2002; BUNTING 2004). [9]

It is not difficult to rehearse the catalogue of indicators available in the UK to support this case; COLEMAN and SCHOFIELD (2003) have provided a well documented digest of concerns. Mental health problems, commonly with adolescent onset, have reached worrying levels-suicidal behaviour and self harm particularly so. Far too many young people, especially females, smoke. 
Levels of alcohol consumption and binge drinking are among the worst in Europe, as is young people's use of illicit drugs. Sexual activity starts increasingly early, with the most vulnerable practising unsafe sex. Sexually transmitted disease and HIV rates are higher than ever, teenage conceptions and abortions among the highest in Europe. School exclusions are hugely on the increase, and antisocial behaviour in all its forms perceived as a growing blight. Official youth crime rates have soared since 1950, with self-reported offending even higher. Neither our youngsters' own futures, nor the society they will constitute, look a pretty sight. [10]

There is, of course, an alternative story to be told. Drawing again on COLEMAN and SCHOFIELD (2003), we may marshal the countervailing evidence to question not necessarily whether the "problem" exists, but how it becomes inflated, stereotyped, to the point of moral panic. Drug use, for example, is mostly short-term, experimental and "soft". Teenage conception rates (albeit high) have decreased steadily over the last five years. Meanwhile, young people are staying longer in education/training, with a corresponding reduction in unemployment. Most striking of all, official youth crime trends have actually moved downwards over the last decade, with young people more likely than others to be the victims, rather than perpetrators, of crime (GOLDSON 2002). And in the broadest sense of all, we are faced with the anomaly that risk taking, or "edgework", is often applauded for adults, but rarely for young people (PLAND \& PLANT 1992; LUPTON 1999). There is a clear case for questioning why young people are so pervasively regarded, even demonised, as risky. [11]

A preliminary step is to locate current public and policy responses to young people and risk within contemporary neo-liberal discourses. Here, residual principles of welfarism remain, but conditionally so, and in tension with the revived distinction between deserving and undeserving. Self-regulation is posited as the route to social inclusion (LUPTON 1999; FORSYTHE \& JORDAN 2002; GARRETT 2003a, 2003b). As for social work, the professional role has become replete with contradictions. Struggling to uphold traditions of support and empowerment for the vulnerable, its role has become primarily disciplinary, "tough love" promoting normative self-regulation where possible, coercion where not (JORDAN 2004). Notable expressions of this can be seen in child and family social work, embedded in the Framework for the Assessment of Children in Need and their Families (DEPARTMENT OF HEALTH 2000) and in the shades of "big brother" lurking behind parenting orders, Information Sharing and Assessment, ID cards and the like (GARRETT 2003a, 2004). Noteworthy, too, has been a terminological shift evidenced in Every Child Matters (DEPARTMENT FOR EDUCATION AND SKILLS 2003) and the Children Act 2004. The overarching designation of children and young people "at risk" has come to embrace not just those in some way at risk of significant harm, but also those in danger of presenting risk to others, or to "preferred futures". Within the risk rhetoric, there has effectively been an elision between the agendas of care and control. In the case of young people, some have argued, concerns with the former have been significantly subsumed, even hijacked, by the latter (GOLDSON 2000, 2002). [12] 
A brief look at the raft of recent policy developments focusing on young people in England and Wales confirms both the blurring of the concept of risk, and the devolution of responsibility for its prevention and management away from social work. At national and local levels, policy initiatives have become polarised between those primarily preventive of social exclusion, and those coercive, for youngsters risky to the rest of us. Into both categories may fall those who engage in one way or another risky behaviour, but the distinction between those deserving support and those warranting correction is never explicit. Either way, with the possible exception of care leavers, they are primarily not the problem of social work. [13]

On the side of reducing risk of social exclusion, we have seen numerous governmental strategies and schemes, in all sectors, targeted at children and young people, aiming among other things to reduce poverty, improve environments and promote participation. We have Education Action Zones, and increased vocational training opportunities. We have multi-agency Health Action Zones, Child and Adolescent Mental Health Services, and, at last, a National Service Framework for those with health or mental health problems. For those at risk of offending, we have preventive schemes such as On Track; for those further along the slippery slope, Youth Offending Teams. For sex education, pregnant or parent teenagers, we have a wide range of initiatives promoted by the Social Exclusion Unit, the Teenage Pregnancy Unit and others. Connexions is now the service to which young people are expected to turn not only for support in progressing from education to work, but with personal problems too. The "joined-upness" and success of these initiatives is much disputed (GOLDSON 2002; DEPARTMENT FOR WORK AND PENSIONS 2004), but it is safe to say that significant gaps remain apparent. The dearth of services for young people with mental health problems, for example, has been well publicised (YOUNG MINDS 2004); a 2004 Department for Education and Skills survey demonstrated that young people may indeed turn to Connexions with educational/vocational issues, but rarely with other problems (DEPARTMENT FOR EDUCATION AND SKILLS 2004). Once upon a time, these might have been for social work. Finally, those young people who have crossed the bureaucratic boundary (at eighteen) between childhood and adulthood must, for the most part, take their chances along with everyone else in the world of adult services. [14]

Beyond this, we come to young people defined as risky not just to themselves, but to "us". Paradoxically, these may now be embraced within the rhetorical category of "at risk", but they or their parents are increasingly designated worthy not of support but surveillance, control, punishment. Certainly, there are preventive and restorative components of policy and practice emerging from recent youth justice legislation (D. SMITH 2003). However, more striking has been the shift in emphasis from "youth justice" to "youth offending", the slide away from mainstream social work intervention, and the thrust towards punitive regulation, itself potentially criminalising (GOLDSON 2002; R. SMITH 2003; WHYTE 2004). For those aged over eighteen years (adults), the thrust of policy, in reality tougher on crime than the causes of crime, is yet more apparent. As for young people's risk taking, whether it merits care or control, neither seems much 
the business of social work any more. To begin to redress the balance, we need to look first at the bases in psychological and social theory upon which youth and risk are configured. [15]

\section{Constructing Youth as a Risky Business}

While the conventional ascription of turbulence to the transitional state of youth is a matter of some dispute (COLEMAN \& HENDRY 1999), most commentators agree that this is a period in which major transitions are to be negotiated, both in the internal self, and with the expectations of the external world. For better or worse, it is represented as a risky business. [16]

For psychologists, this is largely the case by definition. Risk taking itself is regarded as part not only of abnormal but normal development, carrying not just negative but positive consequences. Certainly, we are alerted to the pathological bases of some risk taking behaviours, such as eating disorders and substance misuse (RUTTER \& SMITH 1995). Nonetheless, many normative formulations of adolescent psychology embrace risk taking. Cognitive developmental theory explains it in terms of the growing, but not yet fully developed, capacity to recognise the consequences of their own actions and the perspectives of others (KOHLBERG 1984; HEAVEN 1996). For ELKIND (1967), adolescents' egocentric social cognitions prompt them to develop "personal fables"; the resulting exaggerated concept of invulnerability carries dangers, but emerges from a normal developmental process. Those focusing on identity development argue that young people's risk taking and experimentation are necessary parts of the individualisation process, required for full identity achievement (MARCIA 1966; ERIKSON 1968, 1980). Accordingly, we may imagine, for example, Jane, a sixteenyear-old girl, truanting from school when "bored", smoking a little, clubbing a lot and returning too drunk to remember. While her behaviours might prompt anxiety in those concerned for her best interests, her actions are to be seen simply as steps along the path to individuation and maturity. Indeed, much of the psychological literature presents adolescence as a risky business, but one in which risk taking is not only normal but desired bearing the eventual fruits of integrated sense of self, self-esteem and self-regulation (IRWIN \& MILLSTEIN 1986; JACK 1986). All too often, nonetheless, this induces the "pedagogical paradox"-in the desire to protect young people or ourselves, we prevent them from achieving the maturity that risk taking and learning from mistakes might afford (DE WINTER \& NOOM 2003). [17]

From sociological and other disciplinary perspectives, there are alternative ways of considering youth as a risky business not by definition so much as by virtue of the world we live in. Within these quite disparate discourses, most are agreed that the nature of young people's transitions to adulthood has changed markedly in the space of one generation. Prolonged years in education, later entry into the workforce, reduced state support for independence and delayed home-leaving have made young people's trajectories towards adulthood more protracted, desequenced and fragmented than before (JONES \& WALLACE 1990; JONES 1995; COHEN \& AINLEY 2000; EGRIS 2001). Here, however, the consensus 
ends. What it means to be young in contemporary times is hotly contested, with questions of agency and structure, individualisation, risk and regulation brought to the fore. The terms of this debate are not unfamiliar to academic social work. They have, for example, been exemplified by the engaging "rumble in the jungle" between FERGUSON (2001, 2003), fighting for life politics, and GARRETT (2003b, 2004) for emancipatory politics, with HOUSTON (2004) extending the mediating hand of realism. However, social work has turned little of this theoretical attention towards young people and risk. [18]

Beginning to do so, we may look first to the work of BECK and GIDDENS (BECK et al. 1994; BECK 1998, 1999; GIDDENS 1991, 1999). Both propose that, in the post-traditional order, the social, economic, political and cultural foundations of modern industrial society have been overturned. Risk and uncertainty are the insignia of a "runaway world" (GIDDENS 1999), by virtue of newly manufactured dangers or the dissolution of institutional constraints, destabilised social structures and diminished expert certainties. Individuals are forced to interpret diverse, unpredictable experiences in order to establish their own coherent biographies. No longer regulated by external structures and norms, the self has become a fluid and "reflexive" "biographical project" (GIDDENS 1991). With this comes the potential for all the new freedoms and life choices so gladly trumpeted by "third way" politics. But at the same time, conditions of doubt penetrate all social life; self and identity are necessarily fragile, individualisation becomes a lonely business "full of risks which need to be confronted and fought alone" (BAUMAN 2001, p.xvii). [19]

For young people, the transition to adulthood becomes replete with opportunities and risks. Put positively, "life politics" holds that young people may now as never before be the architects of their own lives, free to negotiate their own pathways, take or avoid their own risks (WALLACE \& KOVATCHEVKA 1998; ESRC 2004a). Jane is freer now than ever to decide to become a doctor, a dancer or a drop-out, to drink, smoke, or to play safe, as her heart and mind dictate. She may invent and re-invent herself as she goes-the agent of her own fulfilment. Put more bleakly, however, the life politics thesis and the culture of individualism increasingly hold young people accountable for their own lives. All too often, the public, policy and personal expectations of responsibility and fulfilment belie lived experience, generating the sense of failure, marginalisation and, for some, mental ill-health (RUTTER \& SMITH 1995; EGRIS 2001). Jane might all too easily, for example, find herself out of work, unskilled, pregnant, lonely and depressed-and all, apparently, a consequence of her own actions. [20]

Challenges to the risk society and individualisation theses have been levelled on several counts. Among the foremost has been that they defy empirical evidence or investigation (ALEXANDER 1996; DINGWALL 1999). Some recent empirical work, however, has attempted to test this, in part confirming the utility of BECK's and GIDDENS' theses. Environmental and health technology risks, for example, have indeed been shown to be more globalised, less recognised and less controllable now than ever. The notion of "organised irresponsibility" has been helpful in explaining and challenging corporate and governmental 
(mis)management of environmental risks (BENN 2004; CROTTY \& CRANE 2004; MATTEN 2004) and risks generated through drug and medical technologies (MØLDRUP \& MORGALL 2001; TURNER 2001; MØLDRUP et al. 2002). However, empirical substantiation of BECK's thesis is less clear when it comes to areas closer to the topic of this paper. TULLOCH and LUPTON (2003), examining risk and risk taking in everyday life, give a mixed verdict. Agreeing with BECK, they find evidence of heightened awareness of risk, and individualised risk calculations made in detachment from traditional ties. Nonetheless, they conclude that "the risk society thesis ... is not sufficiently situated, not sufficiently concerned with localised 'tales from the field'" (TULLOCH \& LUPTON 2003, p.128). Instead, they note how culturally specific and varied are people's perceptions of risk, and how complex are their constructions of it, both negatively and positively. We will return to these themes at a later point, when scrutinising the empirical evidence of young people's risk taking. [21]

For the present, however, the focus of discussion turns to the criticisms of risk society and individualisation theses more prominently to be found in the youth studies literature. The first is that BECK and GIDDENS all but ignore the continuing influence of social structure on individual and social lives; the second, that they elide, or exclude from consideration, issues of power. [22]

The social structural critique recognises the centrality of contemporary preoccupations with risk and individualisation, but disputes their bases in reality. Despite dramatic social and economic change, existing patterns of inequalitypoverty, class, gender and ethnic differences-continue to be reproduced (BOURDIEU 1977; FURLONG \& CARTMEL 1997). This thesis is well represented generally in the social work literature (GOLDSON 2002; GARRETT 2002, 2003a, 2003b), but the particular implications for young people and risk are not well explored. There is, however, sound evidence to suggest that the nature and success of the transition to adulthood are much influenced by class, culture, material and social resources; those less privileged struggle harder, are more exposed to risk and more likely to take it (PARKER et al. 1998; BYNMER 2001; SCHOON \& BYNMER 2003). Seen in this light, Jane's risk taking behavioursnow perhaps stretching to recreational drug use, unsafe sex or antisocial behaviour-might be recognised as escapism from poorly resourced, mundane everyday life. Deeper still, according FURLONG and CARTMEL (1997), cuts the pernicious "epistemological fallacy", generated by a culture of individualism. Young people like Jane are structurally denied opportunity to become stakeholders in the adult world, but encouraged by the culture of individualism to believe themselves accountable. Frustrated and self-blaming, Jane may all the more readily turn to alternative, risky sources of satisfaction and esteem. If we are to understand her behaviour, we need to understand much more fully the complexities of structure and agency involved. [23]

The second major challenge to the BECK/GIDDENS thesis draws on Foucauldian theory, and prompts us to scrutinise our constructions of what is risky and what is not, what within and what beyond the pale. This approach accepts that latemodern society is preoccupied with risk and uncertainty, but holds that both must 
be understood as manifestations of "governmentality" (FOUCAULT 1991). Governmentality denotes the strategies whereby norms, designed to regulate populations and individuals, are discursively generated through "expert knowledges" and deployed through multiple institutions, diverse and localised power relationships (ROSE \& MILLER 1992; ROSE 1996; DEAN 1999; LUPTON 1999). Risk, therefore, exists not as some external reality but as a "calculative rationality" of governance, through which particular groups or individuals may be identified as "at risk" or "high risk", and thereby observed, managed, disciplined. Neo-liberal governmentality, in particular, privileges the norm of self-regulation above all. The individual is invested with moral responsibility, guided by experts to make rational choices over lifestyle, body and mind. Where targeted as a member of a "risky" group, Jane will be in need of extra support to self-regulateto stay in education, to use contraception, to stay within the law. Where she fails meet normative standards, more coercive disciplinary techniques will come into play. [24]

This line of argument, too, has its detractors, not least on grounds of its nondemocratised constructivism, its tendency to downplay both the potential for independent agency and the "reality" of palpable dangers (STRYDOM 2002). Nonetheless, its emphasis on governmental and professional preoccupations with normativity and risk is helpful here. The terms of Foucauldian critique are also familiar enough to academic social work debate; in particular, the co-opting of the profession into the apparatus of "tutelary bureaucracy" has been well highlighted (PEASE \& FOOK 1999; GARRETT 2003a; JORDAN \& JORDAN 2000; JORDAN 2004). But, again, little of this critique has focused directly on young people and risk. By contrast, others in the wider field of youth studies, notably KELLY (2000a, $2000 \mathrm{~b}, 2003$ ) and TAITE (1995), have called into question the way that youth is now constructed as, by definition, a risky category. Risk narratives, they argue, provide the promise, the justification and techniques for regulating young people's behaviour, dispositions and "preferred futures". Institutionalised structural inequalities are recoded as complex but quantifiable factors that place certain groups of young people at risk. Seen this way, the culture of individualism is an expression of the technology of governance that leaves young people feeling accountable for their own fates. Thus, neo-liberal governmentality, desirous of ensuring that Jane and her peers become responsible citizens, constructs her as "at risk" of becoming a "scrounger", a teenage mother, a "yob" by virtue not of her class, culture or circumstances, but of her own risk taking behaviour.

Paradoxically too, the regulatory strategies of governmentality may well prompt in Jane exactly the risk taking behaviour to escape or resist the imperative to selfregulate that they seek to control. But most importantly for KELLY, the danger of youth at risk discourses lies in their relentless pursuit of order and elimination of diversity, projects that "may lend themselves easily and joyously to political uses anytime and everywhere" (BAUMAN 1990, pp.40-1, cited in KELLY 2000b). KELLY would neither dispute nor trivialise the risks that Jane may take; but worse by far would be to stand by and watch her become formed, or transformed, into a Stepford Wife or member of a latter-day Hitler Youth. [25] 
The present discussion, of course, seeks to place young people's risk taking on, not off, the social work agenda. For us, however, the Foucauldian critique is instructive in that it prompts us to reflect critically on our responses to young people and risk. That there is a strong case for further social work understanding of young people's risk taking has already been argued. At the same time, however, we must continue to question whether professional responsibilities lie with encouraging the expression of young people's own identities, or simply promoting those that conform to accepted norms (LORENZ 2000). [26]

\section{Research and Theoretical Insights}

For practitioners to become "epistemically reflexive", they need to be theoretically and research informed, capable of in-depth critical reflection on the constructions influencing their practice (ERAUT 1995; WHITE 1997; IXER 1999). For social workers potentially engaging with risky young people, the challenges are especially daunting-less because existing constructions must be unpicked than because they are little developed in practice. Despite sound enough guides for practice with teenagers (SINCLAIR et al. 1995; TRISELIOTIS et al. 1995; DANIEL \& WASSELL 2002), few of the recent research and theoretical developments in the wider field of youth studies have been noted or absorbed into social work. The ecological model now in vogue in child and family work (BRONFENBRENNER 1979) rests on inexplicit notions of the relationship between individual and context (HOUSTON 2004). Related concepts of vulnerability and resilience tell us more about coping with risk than taking it (DANIEL \& WASSELL 2002). Meanwhile all these constructions tend towards normativity, encouraging us little to question our yardsticks for acceptable or unacceptable risk (GARRETT 2003a). This section of the paper draws together some recent research findings and theoretical formulations in this area that might offer insights for social work practice. The review is exploratory rather than exhaustive or conclusive-it makes a start. [27]

Looking first at patterns (rather than dynamics) of risk taking, there is good evidence from psychological and sociological research to persuade us that young people's welfare and riskiness are associated with their material, cultural and relational contexts, the resources and role models available, and the extent to which they feel connected, supported, recognised (KAGAN 1991; SCHOON \& BYNNER 2003). Several of the behaviours most worrying to policy makers, welfare professionals and public alike-smoking and teenage pregnancy, school exclusion, antisocial behaviour and crime-have been linked to social deprivation, albeit often mediated through family practices (COLEMAN \& HENDRY 1999; SCHOON \& BYNNER 2003). Locality and culture are also influential: a government report in 2002, for example, exposed how locally situated is young people's risky sexual behaviour (Department for Education and Skills 2004). Risk taking and risk perception differ for those growing up in cultures espousing traditional family and community values from those espousing individualism (BRANNEN et al. 1994). Family relationships and parenting styles themselves are influential, too. Where, for example, parents take a negotiative stance, neither overly restrictive nor unprotective, nor giving mixed messages, their teenagers are more 
likely to make socially acceptable and beneficial risk calculations (BRANNEN et al. 1994; GROTEVANT \& COOPER 1998). Finally, peers, too, are powerful mediators of young people's risk choices. Contrary to public perception, this may well be in the direction of regulation rather than deviation (COLEMAN \& HENDRY 1999). Indeed, it seems that young people are more likely to say that they use drugs, in order to "look cool", than actually to do so (see http://www.talktofrank.com/), and also more likely to be influenced by what others do than by what they say (ESRC 2004b). Nonetheless, there is strong evidence that peer groups influence young people's normalisation of risk, and their taking of it-whether in the quest for social identity or kudos, for escapism or thrill, or simply to fit in (HENDRY \& KLOEP 1996; 2000; GREEN et al. 2000;

DENSCOMBE 2001; LAWY 2002; FRANCE 2000). As for Jane, we know little or nothing of any of these elements in her life; were we seeking to work effectively with her as social workers, we would need to find out. [28]

This brief overview of risk taking patterns and their associations is sufficient to persuade us that none of the models of self-inventing free agent, nor sociostructurally determined enactor, nor (un)regulated self-regulator, is alone sufficient to explain young people's risk taking, nor what we make of it. Exploration of recent research on the dynamics and constructions of risk taking, however, may take our understanding further. [29]

Several recent studies of young people's risk taking have thrown light on the complex interplay of individual decision-making, identity and context. COHEN and AINLEY (2000), for example, draw on cultural learning theory (LAVE \& WENGER 1991 ) to highlight how young people develop their identities through learning in situated contexts of family, peers and community. Increasingly expected to manage their own reflexive life projects, their learning and choice making are locally and structurally situated. Likewise, according to LAWY:

"risk, identity and learning are mutually constituative ... the challenge facing ... young people (is) to seam together risk, identity and learning within a coherent narrative, and to do so in the face of competing interests and structural limits in the knowledge that the balance between them might, at any moment, be changed" (LAWY 2002, p.407). [30]

For Jane, as for her peers, the meaning of risk taking-be it about "normal" experiment, or normalised riskiness, escapism, or pursuit of status and pleasure will be fluid, learned and shaped as she develops her identity in contexts. INGHAM et al. (1993) and SHINER and NEWBURN (1997), for example, show us how young people's risk beliefs about sex or drugs become habituated, mediated through social relationships, transmitted wisdoms, localised myths, and experience-based knowledges. GREEN et al. (2000) demonstrate how young people construct normalising risk hierarchies, with associated risk reputations conferring status or stigma, in social and cultural contexts. There will also be power dimensions influencing the risk choices made in context. Girls like Jane, for example, may feel disempowered from pursuing "condom negotiations", or may 
choose to smoke to resist the authority of the "good girl" image (FRANCE, 2000). And so the interplay of agency and identity, structure and context, turns. [31]

To take our understanding further, we may look beyond the empirical to certain theoretical formulations that might inform the study of youth, transition and risk. Emerging from a range of disciplines, these are not easily stitched together without risk of obscuring their distinctions. What they share, however, is common recognition of the need to move beyond the dualism of structure and agency. First, we may look to the constructs of social, individual or identity capital. While for PUTMAN (2000) social capital is predominantly an attribute of communities, for COLEMAN (1988) it denotes the access of individuals to resources, information, networks and trustworthy relationships, as the basis for action. RAFFO and REEVES (2000), for example, echo the latter formulation, in suggesting that an "individualised system of social capital" evolves for each young person. For Jane, like others, this takes shape in the context of the material and symbolic resources available to her, in the social, cultural, economic and temporal spaces that she inhabits. Her individualised system of social capital may either support or constrain her actions, her choices and, in turn, her outcomes. CÔTÉ (2002), focusing more on identity formation, elaborates on how both the "tangible" identity capital resources (material, class, gender, access) available to each young person, and the "intangible" (personality, relationship qualities, intellectual attributes), will differ. As Jane deploys these, they will cumulatively differentiate her from others, influencing the investments she makes in her own life and the risks she takes. [32]

While CÔTÉ's thesis highlights the uniqueness of individual transitions to adulthood, the cultural theorists of risk, DOUGLAS $(1966,1992)$ and LASH $(1993,2000)$ encourage us to focus on commonalities. Though their work is not yet well incorporated into the field of youth studies, both highlight the importance of risk cultures, of shared notions of risk within cultures and communities. For DOUGLAS, risk perceptions and risk choices are highly symbolic, delineating the boundaries between self and other. For LASH, they are aesthetic understandings and judgements, mediated through lifestyles and membership of social groups. Jane's behaviour and perceptions of what it means to drop out, to use drugs, to have unsafe sex, will bear far more relation to what is "normal", "cool" or assumed within her reference group than it will to any external calculation of risk. Finally, BOURDIEU $(1986,1990)$, arguably occupying some middle ground between identity capital theorists and cultural theorists, is directly concerned both with the individuality of actions and their embeddedness in cultural and structural contexts. In hierarchical social spaces, young people have different economic and cultural capital resources, and differential access to the "rules of the game" of lifestyle and choice. Their choices may be understood in terms of "habitus": the system of interconnected dispositions that help us interpret our surrounding world. Jane's choices are indeed her own, but are steered by her life experiences, the culture and contexts she lives in and the capital she accrues; they are unique to her, but they may also be shared. EVANS (2002), putting forward the related concept of "bounded agency", expresses a similar view. For social work in particular, her conclusion is worthy of note: 
"Young people are social actors in a social landscape. How they perceive the horizons depends on where they stand in the landscape and where their journey takes them. Where they go depends on the pathways they perceive, choose, stumble across or clear for themselves, the terrain and the elements they encounter. Their progress depends on how well they are equipped, the help they can call on when they need it, whether they go alone or together and who their fellow travellers are. If policies and interventions are to be made effective, we need to sharpen our awareness of the interplay of structural forces and individual's attempts to control their lives" (EVANS 2002, p.265). [33]

\section{Conclusion-Implications for Social Work}

This discussion has sought to explore and to set on the social work agenda both young people's risk taking and risk making-our construction of youth as a risky business. There is a central paradox here: why bother critiquing professional and policy fixations with young people as risk when social work of all disciplines pays them little attention at all? The answer is that simply the fact that young people have become, by default, "not social work's problem" neither explains nor justifies their omission. It is not difficult to marshal the evidence of research and lived experience confirming that youth is potentially a risky time, either by definition or particularly in contemporary times. That the "problem" should not be sidestepped by social work is a starting point. How it may be addressed must be the subject of further discussion and research; this paper aims not to conclude but to open the debate. [34]

This said, three points stand out for social work thus far. First, there is indeed a wide range of research and theory from related disciplines that might inform social work thinking and practice with young people and risk. While some constructs explored-social structuralist, post-modernist, Foucauldian-are familiar enough in academic social work, few have been applied directly to young people, and fewer or none incorporated into the packages of "ready-made" knowledges available for practitioners (TAYLOR 2004). Perhaps this is no bad thing. However challenging it may be to make collective sense of research and theoretical insights coming from quite disparate sources, we have the chance to do so, without the need to subvert existing entrenched wisdoms. For critical and reflexive social work practice, this can only be an opportunity. [35]

A second key message must be that when we seek to understand young people's risk taking, we need to consider them as agents of their own lives, pursuing their own trajectories, situated within their own social, material, cultural and relational worlds. Neither the life politics of reflexive individualisation, nor the determinism of social structuralism, nor the regulatory thrust of govern-mentality, is sufficient to explain the complex interplay of agency, structure and power involved. To understand these, we need to look more closely at what risk taking means to young people, its dynamics, and the relationships and resources surrounding it. We might also draw on some particular concepts risk culture, cultural learning, identity capital or habitus to elucidate. Most importantly, we must recognise that risk taking is integrally bound up with the development of young people's 
identities. To problematise this is a necessary and productive activity for informing practice. But to consider risk taking always and necessarily problematic would be missing the point. We must start by recognising risk taking as a routine, even desirable, component of young people's lives and development. Where and how we begin to define it as troubling or troublesome must then be up for scrutiny. [36]

This brings us to the third and final message for social work: that we must look not only to what risk taking means in young people's lives, but to what we "make it" in our professional minds and actions. Rather than simply going along with neo-liberal orthodoxies, we need consistently to question the distinction between what is normal and abnormal, acceptable and unacceptable risk - between youth in transition, youth in trouble and youth as trouble. If we are to aspire to social work practice with young people that is critically reflexive and embraces uncertainty (TAYLOR \& WHITE 2000, 2001), that is constructive and dialogical (PARTON \& O'BRYNE 2000a, 2000b; PEASE 2002), and that maintains its longheld commitment to mediating individuals and society, we could do worse than start from here. [37]

\section{References}

Alexander, Jeffrey (1996). Critical reflections on "reflexive modernisation". Theory, Culture and Society, 13, 133-8.

Bauman, Zygmunt (2001). The individualized society. Cambridge: Polity Press.

Beck, Ulrich (1998). Risk society. London: Sage.

Beck, Ulrich (1999). World risk society. Cambridge: Polity Press.

Beck, Ulrich, Giddens, Anthony \& Lash, Scott (1994). Preface. In Ulrich Beck, Anthony Giddens \& Scott Lash (Eds.), Reflexive modernisation: Politics, tradition and aesthetics in the modern social order (pp.vi-viii). Cambridge: Polity.

Benn, Suzanne (2004). Managing toxic chemicals in Australia: a regional analysis of the risk society. Journal of Risk Research, 7(4), 399-412.

Bourdieu, Pierre (1977). Cultural reproduction and social reproduction. In Jerome Karabel \& Albert H. Halsey (Eds.), Power and ideology in education (pp.487-511). Oxford: Oxford University Press.

Bourdieu, Pierre (1986). The forms of capital. In John Richardson (Ed.), Handbook of theory and research for the sociology of education (pp.241-258). New York: Greenwood Press.

Bourdieu, Pierre (1990). In other words: Essays towards a reflexive sociology. Cambridge: Polity Press.

Brannen, Julia, Dodd, Katharyn, Oakley, Ann \& Storey, Pamela (1994). Young people, health and family life. Buckingham: Open University Press.

Bronfenbrenner, Uri (1979). The ecology of human development. Cambridge MA: Harvard University Press.

Bunting, Lisa \& McAuley, Colette (2004a). Research review: Teenage pregnancy and motherhood: the role of support. Child and Family Social Work, 9(2), 207-15.

Bunting, Lisa \& McAuley, Colette (2004b). Research review: Teenage pregnancy and parenthoodthe role of fathers. Child and Family Social Work, 9(3), 295-304.

Bunting, Madeleine (2004). Today's youth: anxious, depressed, anti-social. The Guardian, 13 September 2004, pp.1-4.

Bynner, John (2001). British youth transitions in comparative perspective. Journal of Youth Studies, 4(1), 5-23. 
Cohen, Philip \& Ainley, Pat (2000). In the country of the blind? Youth studies and cultural studies in Britain. Journal of Youth Studies, 3(1), 79-95.

Coleman, John (1988). Social capital in the creation of human capital. American Journal of Sociology, 94, S95-S120.

Coleman, John \& Hendry, Leo (1999). The nature of adolescence (3rd ed.). London: Routledge.

Coleman, John \& Schofield, Jane (2003). Key data on adolescence. Brighton: Trust for the Study of Adolescence.

Côté, James (2002). The role of identity capital in the transition to adulthood: the individualization thesis examined. Journal of Youth Studies, 5(2), 117-34.

Crotty, Jo \& Crane, Andrew (2004). Transitions in environmental risk in a transitional economy: management, capability and community trust in Russia. Journal of Risk Research, 7(4), 413-30.

Daniel, Brigid \& Wassell, Sally (2002). Adolescence: Assessing and promoting resilience in vulnerable children 3. London: Jessica Kingsley.

Davis, Cindy, Tang, Catharine \& Ko, Janet (2002). Assessing the impact of social factors on the mental health of Chinese at risk adolescents in Hong Kong. British Journal of Social Work, 32(5), 609-19.

de Winter, Micha \& Noom, Marc (2003). "Someone who treats you as an ordinary human being ..." Homeless youth examine the quality of professional care. British Journal of Social Work, 33(3), 325-37.

Dean, Mitchell (1999). Governmentality. London: Sage.

Denscombe, Martin (2001). Uncertain identities: The value of smoking for young adults in late modernity. British Journal of Sociology, 52(1), 157-78.

Department for Education and Skills (2003). Every child matters. Green Paper: London, DfES. Available at: http://www.dfes.gov.uk/everychildmatters/ [Date of access: December $\left.1^{\text {st }}, 2005\right]$.

Department for Education and Skills (2004). Improve your connexions: The connexions customer satisfaction survey. London: DfES.

Department for Work and Pensions (2004). Opportunity for all sixth annual report, 2004. London, DWP. Available at: http://www.dwp.gov.uk/ofa/ [Date of access: December $\left.1^{\text {st }}, 2005\right]$.

Department of Health (1996). Focus on teenagers. London: Department of Health.

Department of Health, Department for Education and Employment, and Home Office (2000). Framework for the assessment of children in need and their families. London: The Stationery Office.

Dingwall, Robert (1999). "Risk society": The cult of theory and the millennium? Social Policy and Administration, 33(4), 474-91.

Douglas, Mary (1966). Purity and danger: An analysis of concepts of pollution and taboo. London: Routledge and Kegan Paul.

Douglas, Mary (1992). Risk and blame: Essays in cultural theory. London: Routledge.

EGRIS: European Group for Integrated Social Research (2001). Misleading trajectories: Transition dilemmas of young adults in Europe. Journal of Youth Studies, 4(1), 101-18.

Elkind, David (1967). Egocentrism in adolescence. Child Development, 38, 1025-34.

Eraut, Michael (1995). Schon shock: A case for reframing reflection in action. Teachers and Teaching, 1(1), 9-22.

Erikson, Eric (1980). Identity and life cycle. New York: Norton.

Erikson, Eric (1968). Identity, youth and crisis. New York: Norton.

ESRC (2004a). ESRC priority network: Pathways into and out of crime-risk, resilience and diversity. ESRC, Network News, Issue 1, January 2004.

ESRC (2004b). Unconscious effects of prototypes on young people's health and behaviour. Available at: http://www.esrc.ac.uk/esrccontent/news/ [Date of access: December $\left.1^{\text {st }}, 2005\right]$.

Evans, Karen (2002). Taking control of their lives? Agency in young adult transitions in England and the new Germany. Journal of Youth Studies, 5(3), 245-69. 
Ferguson, Harry (2001). Social work, individualization and life politics. British Journal of Social Work, 31(1), 41-55.

Ferguson, Harry (2003). In defence (and celebration) of individualization and life politics for social work. British Journal of Social Work, 33(5), 699-707.

Forsythe, Bill \& Jordan, Bill (2002). The Victorian ethical foundations of social work in England: Continuity and contradiction. British Journal of Social Work, 32(7), 847-62.

Foucault, Michel (1991). Governmentality. In Graham Burchell, Colin Gordon \& Peter Miller (Eds.), The Foucault effect: Studies in governmental rationality (pp.87-104). Chicago: University of Chicago Press.

France, Alan (2000). Towards a sociological understanding of youth and their risk-taking. Journal of Youth Studies, 3(3), 317-31.

Furlong, Andy \& Cartmel, Fred (1997). Young people and social change: Individualisation and risk in late modernity. Buckingham: Open University Press.

Garrett, Paul Michael (2002). "Yes Minister": Reviewing the "looking after children" experience and identifying the messages for social work research. British Journal of Social Work, 32(7), 831-46.

Garrett, Paul Michael (2003a). Swimming with dolphins: The assessment framework, New Labour, and new tools for social work with children and families. British Journal of Social Work, 33(4), 44163.

Garrett, Paul Michael (2003b). The trouble with Harry: Why the "New agenda of life politics" fails to convince. British Journal of Social Work, 33(3), 381-97.

Garrett, Paul Michael (2004). More trouble with Harry: A rejoinder in the "life politics" debate. British Journal of Social Work, 34(4), 577-89.

Giddens, Anthony (1991). Modernity and self identity: Self and society in the late modern age. Oxford: Polity.

Giddens, Anthony (1999). Runaway world. London: Profile Books.

Goldson, Barry (2000). "Children in need" or "young offenders"? Hardening ideology, organizational change and new challenges for social work with children in trouble. Child and Family Social Work, 5(3), 255-65.

Goldson, Barry (2002). New Labour, social justice and children: Political calculation and the deserving-undeserving schism. British Journal of Social Work, 32(6), 683-95.

Green, Eileen, Mitchell, Wendy \& Bunton, Robin (2000). Contextualizing risk and danger: An analysis of young people's perceptions of risk. Journal of Youth Studies, 3(2), 109-26.

Grotevant, Harold \& Cooper, Catherine (1998). Individuality and connectedness in adolescent development: Review and prospects for research on identity, relationships and context. In Eva Skoe, \& Anna von der Lippe (Eds.), Personality development in adolescence: A cross-national and lifespan perspective (pp.3-37). London: Routledge.

Heaven, Patrick (1996). Adolescent health. London: Routledge.

Hendry, Leo \& Kloep, Marion (1996). Is there life beyond "flow"? Proceedings of the 5th Biennial Conference of the EARA, University of Liege, May 1996.

Home Office (2003). Youth justice: The next steps. London: Home Office.

Houston, Stan (2004). Garrett contra Ferguson: A meta-theoretical appraisal of the "rumble in the jungle". British Journal of Social Work, 34(2), 261-7.

Ingham, Roger, Woodcock, Alison \& Stenner, Karen (1993). The limitations of rational decisionmaking models as applied to young people's sexual behaviour. In Peter Aggleton, Peter Davies \& Graham Hart (Eds.), AIDS: Rights, risk and reason (pp.163-173). London: Falmer Press.

Irwin, Charles \& Millstein, Susan (1986). Biosocial correlates of risk taking behaviours during adolescence. Can the physician intervene? Journal of Adolescent Health, 7(6), S82-S96.

Ixer, Graham (1999). No such thing as reflection. British Journal of Social Work, 29(4), 513-27.

Jack, M. S. (1986). Personal fable: A potential explanation for risk-taking behaviour in adolescents. Journal of Pediatric Nurse, 4(5), 334-8.

Jessor, Richard (1984). Adolescent development and behavioural health. In Joseph Matarazzo, J. Weiss, J. Herd, N. Miller \& S. Weiss (Eds.), Behavioural health: A handbook of health and enhancement and disease prevention (pp.69-90). New York: John Wiley and Sons. 
Jones, Gill (1995). Leaving Home. Buckingham: Open University Press.

Jones, Gill \& Wallace, Claire (1990). Beyond individualisation: what sort of social change? In Lynn Chisholm, Peter Büchner, Heinz-Hermann Krüger \& Phillip Brown (Eds.), Childhood, youth and social change: A comparative perspective (pp.144-154). London: Falmer.

Jordan, Bill (2004). Emancipatory social work? Opportunity or oxymoron. British Journal of Social Work, 34(1), 5-19.

Jordan, Bill \& Jordan, Charlie (2000). Social work and the third way. London: Sage.

Kagan, Jerome (1991). Stages in adolescent involvement in drug use. Science, 190, 912-14.

Kelly, Peter (2000a). The dangerousness of youth-at-risk: The possibilities of surveillance and intervention in uncertain times. Journal of Adolescence, 23(4), 463-76.

Kelly, Peter (2000b). Youth as an artefact of expertise: Problematizing the practice of youth studies in an age of uncertainty. Journal of Youth Studies, 3(3), 301-15.

Kelly, Peter (2003). Growing up as risky business? Risks, surveillance and the institutionalized mistrust of youth. Journal of Youth Studies, 6(2), 165-80.

Kohlberg, L. (1984). The psychology of moral development: The nature and validity of moral stages: Essays on moral development. San Francisco: Harper.

Lash, Scott (1993). Reflexive modernisation: The aesthetic dimension. Theory Culture and Society, $10,1-23$

Lash, Scott (2000). Risk culture. In Barbara Adam, Ulrich Beck \& Jost van Loon (Eds.), The risk society and beyond (pp.47-62). London: Sage.

Lave, Jean \& Wenger, Etienne (1991) Informal situated learning. Cambridge: Cambridge University Press.

Lawy, Robert (2002). Risky stories: Youth identities, learning and everyday risk. Journal of Youth Studies, 5(4), 407-23.

Lorenz, Walter (2000). Contentious identities: Social work and the search for professional and personal identities, ESRC Theorising Social Work Research, Seminar 6.

Lupton, Deborah (1999). Risk. London: Routledge.

Marcia, James E. (1966). Development and validation of ego-identity status. Journal of Personality and Social Psychology, 3, 551-8.

Matten, Dirk (2004). The impact of the risk society thesis on environmental politics and management in a globalising economy: Principles, proficiency, perspectives. Journal of Risk Research, 7(4), 377-98.

Møldrup, Claus \& Morgall, Janine Marie (2001). Risk society: reconsidered in a drug context. Health, Risk and Society, 3(1), 59-74.

Møldrup, Claus, Morgall, Janine Marie \& Almarsdóttir, Anna Birna (2002). Perceived risk of future drugs: A Danish citizen Delphi. Health, Risk and Society, 4(1), 5-18.

Office of National Statistics (2004). The health of children and young people. London: ONS.

Parker, Howard, Aldridge, Judith \& Measham, Fiona (1998). Illegal leisure: The normalisation of adolescent recreational drug use. London: Routledge.

Parton, Nigel \& O'Byrne, Patrick (2000a). Constructive social work: Towards a new practice. London: Macmillan and New York: St Martin's Press.

Parton, Nigel \& O'Byrne, Patrick (2000b). What is constructive social work? Critical Social Work, 1(2), Fall. Available at: http://www.CriticalSocialWork.com/00-2-what-parton.html [Date of access: December $\left.1^{\text {st }}, 2005\right]$.

Pease, Bob (2002). Rethinking empowerment: A postmodern reappraisal for emancipatory practice. British Journal of Social Work, 32(2), 135-47.

Pease, Bob \& Fook, Janet (Eds.) (1999). Transforming social work practice: Postmodern critical perspectives. Sydney: Allen and Unwin.

Plant, Martin \& Plant, Moira (1992). Risk-takers: Alcohol, drugs, sex and youth. London: Routledge.

Putnam, Robert (2000). Bowling alone: The collapse and revival of American community. New York: Simon and Schuster. 
Raffo, Carlo \& Reeves, Michelle (2000). Youth transitions and social exclusion: Developments in social capital theory. Journal of Youth Studies, 3(2), 147-66.

Rose, Nikolas (1996) Governing "advanced" liberal democracies. In Andrew Barry, Thomas Osborne \& Nikolas Rose (Eds.), Foucault and political reason: Liberalism, neo-liberalism and rationalities of government (pp.37-64). London: University College London Press.

Rose, Nikolas \& Miller, Peter (1992). Political power beyond the state: Problematics of government. Journal of Sociology, 43(24), 173-205.

Rutter, Michael \& Smith, David (Eds.) (1995). Psychological disorders in young people: Time trends and their causes. London: John Wiley and Sons.

Schoon, Ingrid \& Bynner, John (2003). Risk and resilience in the life course: Implications for interventions and social policies. Journal of Youth Studies, 6(1), 21-31.

Shiner, Michael \& Newburn, Tim (1997). Definitely, maybe not? The normalisation of recreational drug use amongst young people. Sociology, 31(3), 511-30.

Sinclair, Ruth, Garnett, Louise \& Berridge, David (1995). Social work and assessment with adolescents. London: National Children's Bureau.

Smith, David (2003). New Labour and youth justice. Children \& Society, 17(3), 226-35.

Smith, Roger (2003). Youth justice: Ideas, policy and practice. Cullompton: Willan Publishing.

Social Exclusion Unit (1999). Bridging the gap: New opportunities for 16-18 year-olds not in education, employment or training. London: The Stationery Office.

Social Exclusion Unit (2000a). National strategy for neighbourhood renewal: A frame-work for consultation. London: Cabinet Office.

Social Exclusion Unit (2000b). Report of policy action team 12 on young people. London: The Stationery Office.

Stead, Joan, Lloyd, Gwynned \& Kendrick, Andrew (2004). Participation or practice innovation: Tensions in inter-agency working to address disciplinary exclusion from school. Children \& Society, 18(1), 42-52.

Stevens, Irene (2004). Cognitive-behavioural interventions for adolescents in residential child care in Scotland. Child and Family Social Work, 9(3), 237-46.

Strydom, Piet (2002). Risk, environment and society: Ongoing debates, current issues and future prospects. Buckingham: Open University Press.

Taite, G. (1995). Shaping the "at risk youth": risk, governmentality and the Finn Report. Discourse, $16,123-34$.

Taylor, Carolyn (2004). Underpinning knowledge for child care practice: Reconsidering child development theory. Child and Family Social Work, 9(3), 225-36.

Taylor, Carolyn \& White, Sue (2000). Practising reflexivity in health and welfare: Making knowledge. Buckingham: Open University.

Taylor, Carlolyn \& White, Sue (2001). Knowledge, truth and reflexivity: The problem of judgement in social work. Journal of Social Work, 1(1), 37-59.

Triseliotis, John, Borland, Moira, Hill, Malcolm \& Lambert, Lydia (1995). Teenagers and the Social Work Services. London: HMSO.

Tulloch, John \& Lupton, Deborah (2003). Risk and everyday life. London: Sage.

Turner, Bryan (2001). Risks, rights and regulation: An overview. Health, Risk and Society, 3(1), 918.

Wallace, Claire \& Kovatchevka, Sijka (1998). Youth cultures and consumption in Eastern and Western Europe. Youth and Society, 28, 189-214.

White, Sue (1997). Beyond retroduction? Hermeneutics, reflexivity and social work practice. British Journal of Social Work, 27(5), 739-53.

Whyte, Bill (2004). Responding to youth crime in Scotland. British Journal of Social Work, 34(3), 395-411.

Young Minds (2004). Mental health services for adolescents and young adults. Available at: http://www.youngminds.org.uk/adolescentpolicy/ [Date of access: December $\left.1^{\text {st }}, 2005\right]$. 


\section{Author}

Elaine SHARLAND is a Lecturer in the School of

Contact:

Social Work and Social Care at the University of

Dr Elaine Sharland

Sussex.

School of Social Work and Social Care

Essex House

University of Sussex

Falmer, Brighton BN1 9RQ, UK

E-mail: E.Sharland@sussex.ac.uk

\section{Citation}

Sharland, Elaine (2006). Young People, Risk Taking and Risk Making: Some Thoughts for Social Work [37 paragraphs]. Forum Qualitative Sozialforschung / Forum: Qualitative Social Research, 7(1), Art. 23, http://nbn-resolving.de/urn:nbn:de:0114-fqs0601230. 